\title{
Chlorite of hydrothermal origin in the Strzelin and Borów granites (Fore-Sudetic Block, Poland)
}

\author{
Justyna CIESIELCZUK
}

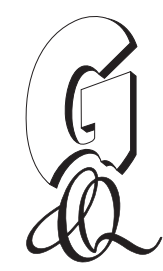

Ciesielczuk J. (2012) - Chlorite of hydrothermal origin in the Strzelin and Borów granites (Fore-Sudetic Block, Poland). Geol. Quart., 56 (2): 333-344, doi: $10.7306 /$ gq. 1025

\begin{abstract}
Chlorite, a product of very low- to low-grade metamorphism, is frequently used as a geothermometer because of the fact that its structure and chemical composition can reflect the physical and chemical conditions of its formation. In the hydrothermally altered Strzelin and Borów granites (the Fore-Sudetic Block, Poland) chlorite is ubiquitous. It is found in two forms: spherulitic and post-biotite, and was formed in different ways in different parts of the Strzelin and Borów granites: as result of (1) replacement of biotite or (2) crystallisation from fluid. The chlorite formed in the Borów granite shows a higher Fe content than that in the Strzelin granite, a feature related to the content of $\mathrm{Mg}$ and $\mathrm{Fe}$ in the host rock. Temperatures of chlorite formation are the lowest for unaltered granite and then gradually increase for slightly, moderately and strongly altered granite and are the highest in hydrothermal veins. This means that the temperature of the hydrothermal fluid was higher than that of the altered granitic bodies. Moreover, the spherulitic chlorite formed at a higher temperature than did the post-biotite chlorite, and is usually smaller because biotite replacement lasted longer than did the crystallisation of spherulitic chlorite directly from hydrothermal fluid. Such patterns are likely to occur in other granitic bodies.
\end{abstract}

Justyna Ciesielczuk, Faculty of Earth Sciences, University of Silesia, Bedzińska 60, 41-200 Sosnowiec, Poland, e-mail: justyna.ciesielczuk@us.edu.pl (received: May 05, 2011, accepted: March 23, 2012; first published online: June 11, 2012).

Key words: chlorite, hydrothermal alteration, granite, geothermometer, Fore-Sudetic Block.

\section{INTRODUCTION}

Chlorite can crystallise in a number of different environments. It is a ubiquitous product of very low- to low-grade metamorphism influencing a great variety of rocks of different formation age such as in Cambrian basaltic vesicular lavas (Lopez-Munguira et al., 2002), Late Jurassic shallow-marine sandstones (Ryan and Hillier, 2002) and early Oligocene sandstones and greywackes with andesitic volcanic clasts (Schmidt and Livi, 1999). It is also one of the most abundant and widespread alteration products in geo- or hydrothermal environments such as in the Neogene Kuroko $\mathrm{Cu}-\mathrm{Pb}-\mathrm{Zn}$ vein-type deposits of Japan (Shikazono and Kawahata, 1987), in quartz/carbonate hydrothermal veins in amphibolites and gneisses of the Sobotín region and pegmatites of the Žulová and the Strzegom-Sobótka massifs (Zimák, 1999), in Cretaceous granitic rocks at Ashio (Hamasaki et al., 1995) and Variscan granitic massifs of the Karkonosze (Wilamowski, 2002; Kozłowski and Marcinowska, 2007) and Strzelin areas (Ciesielczuk and Janeczek, 2004; Kozłowski and Marcinowska, 2007).
Chlorite group displays a wide range of chemical composition, which can vary depending on the conditions of formation (e.g., Cathelineau and Nieva, 1985; Bailey, 1988; Cathelineau, 1988; Battaglia, 1999; Schmidt and Livi, 1999; Krzemiński, 2000; Zimák, 1999; Vidal et al., 2005; Plissart and Féménias, 2009). A general crystallochemical formula of chlorite can be given as follows (de Caritat et al., 1993):

$$
\left(\mathrm{R}_{u}^{2+} \mathrm{R}_{y}^{3+} \mathrm{Z}_{z}\right)^{\mathrm{VI}}\left(\mathrm{Si}_{4-x} \mathrm{Al}_{x}\right)^{\mathrm{IV}} \mathrm{O}_{10+w}(\mathrm{OH})_{8-w}
$$

where: $u+y+z=6, z=(y-w-x) / 2, w$ frequently reaches zero, $\mathrm{R}^{2+}$ usually represents $\mathrm{Mg}^{2+}$ or $\mathrm{Fe}^{2+}, \mathrm{R}^{3+}$ typically represents $\mathrm{Al}^{3+}$ or $\mathrm{Fe}^{3+}$, and $\square$ represents structural vacancies. Superscripts VI and IV denote octahedral and tetrahedral occupancy, respectively.

The main factor which controls chlorite formation in either metamorphic or hydrothermal processes is temperature, and so a number of attempts at using chlorite as a geothermometer have been made. However, chlorite geothermometry was criticized, even discredited, by Jiang et al. (1994). What is more, Frey and Robinson (1999) warned against using the chlorite geothermometer as a function of its chemical composition, par- 
ticularly for chlorites formed at low temperatures. According to them this is only possible for homogeneous phases formed in conditions of thermodynamic equilibrium. Nevertheless, the application of chemical composition of chlorite as a geothermometer has not been abandoned (Walshe, 1986; Merriman et al., 1995; Zang and Fyfe, 1995; Xie et al., 1997; Zang et al., 1997; Zimák, 1999; Krzemiński, 2000; Vidal et al., 2001, 2005; Plissart and Féménias, 2009), though is approached with considerable caution. Also, Parra et al. (2005) experimentally showed that the Si-content of chlorite is sensitive to temperature for the various divariant assemblages. Chlorite geothermometry has been modified, as by Battaglia (1999), for example, who exploite X-ray diffraction patterns in chlorite to this end, and by Inoue et al. (2009). Given the usefulness of geothermometers in geology, this ubiquitous mineral provides a simple and easy means of establishing conditions of the host rock formation.

This paper describes the characteristics of chlorite formed during the hydrothermal alteration of granitoids from two Variscan granitic massifs: the Strzelin and the Strzegom-Sobótka massifs, in the Fore-Sudetic Block of SW Poland. These two localities were chosen because of the varied patterns of alteration of the host rock: (1) gradational, as in the Strzelin granite, and (2) complex, as in the shear zone cropping out in the Borów quarry within the Strzegom-Sobótka granite. Also, some comments on the application of the chlorite geothermometer are made.

\section{GEOLOGICAL SETTING AND PETROGRAPHY}

The Strzelin granite builds the northern part of the Strzelin Massif. Petrographically it is fine-grained biotite granite accompanied by more leucocratic medium-grained biotite granite (Borkowska, 1956; Bereś, 1969). The age of the Strzelin granite was established by the ${ }^{87} \mathrm{Rb} /{ }^{86} \mathrm{Sr}$ method as $347 \pm 12 \mathrm{Ma}$ (Oberc-Dziedzic et al., 1996). Moreover, Oberc-Dziedzic et al. (1996), and Oberc-Dziedzic (1999, 2007) distinguished dykes of younger $(330 \pm 6 \mathrm{Ma})$, light biotite-muscovite granite within the biotite granite. Hydrothermal alteration of the Strzelin granite resulted in the formation of mineralised veins and subsequent alteration of the surrounding granite, the effects being seen in a large active quarry located east of the city of Strzelin. Based on the content of biotite, spherulitic and post-biotite chlorite and the kind and amount of other hydrothermal minerals, three stages of alteration of the Strzelin granite around hydrothermal veins have been distinguished: (1) slightly altered granite, (2) moderately altered granite and (3) strongly altered granite. Strongly altered granite lacks biotite and is usually depleted in quartz. Albite and microcline are the only feldspars. Hydrothermal minerals such as spherulitic chlorite, prehnite, clinozoisite, laumontite, calcite, and muscovite are abundant. This granite facies is usually bleached. The slightly altered granite differs from the unaltered one in the prevalence of post-biotite chlorite over biotite and in the presence of scarce minute hydrothermal minerals such as albite, spherulitic chlorite, titanite and prehnite. In the moderately altered granite almost all of the biotite is replaced by chlorite, while the feldspars are also altered. Hydrothermal minerals are found in large quantities. The size of hydrothermal minerals increases with the degree of alteration and the mineral assemblage changes with depth (Ciesielczuk, 2000b; Ciesielczuk and Janeczek, 2004; Ciesielczuk, 2007).

The granite cropping out in the Borów quarry is part of a biotite-hornblende granite (Puziewicz, 1990), and is called the Strzegom granite (Majerowicz, 1972), or a granite of the Kostrza type (Kural and Morawski, 1968). It is part of the Strzegom-Sobótka Variscan granitoid massif. Its age was established by the Rb-Sr method for 325-330 Ma (Pin et al., 1989 ) and by means of the $\mathrm{Pb}-\mathrm{Pb}$ zircon method as $303 \pm 2 \mathrm{Ma}$ (Turniak et al., 2005). Specimens containing hydrothermal chlorite were collected from the large (approximately $80 \mathrm{~m}$ ) shear zone exposed in the northern wall of the Borów 17 quarry. This zone is cut by many hydrothermal subvertical veins, mostly of E-W strike, filled mainly with quartz. Granite in this zone is strongly altered with metre-scale variations (Ciesielczuk, 2000a). A specimen of unaltered, medium-grained granite was collected next to the shear zone and consists of plagioclase, microcline, quartz and biotite, with accessory titanite, zircon and apatite. The altered Borów granite contains albite and/or microcline, quartz, chlorite and pyrite. Minute amounts of muscovite, prehnite, titanite, zircon and apatite were also found.

Chlorite in both locations is of hydrothermal origin, but the effect of hydrothermal alteration varies (Ciesielczuk, 2002). Alteration in the Strzelin granite produced an abundance of hydrothermal minerals and is gradational and restricted to a few centimetre-wide (on average) zones around veins and fractures whereas in the Borów granite the entire granite in the shear zone is strongly altered, though its mineralogical composition is simple.

\section{ANALYTICAL METHODS}

More than one hundred samples of altered and unaltered Strzelin and Borów granites were collected in the field. Subsequently thin sections were prepared of representative samples: 21 from the Strzelin granite and 17 from the Borów granite and examined by standard polarizing microscope. Then, selected chlorite grains from unaltered and altered granites and hydrothermal veins were examined by means of scanning electron microscopy (SEM) JSM 35C (University of Silesia, Poland) and Jeol-JSM 5410 (Jagiellonian University, Poland). Additionally, fragments of hydrothermal vein fillings were prepared and viewed by SEM in environmental mode to observe the habits and succession of minerals formed in the hydrothermal veins.

The chemical composition of the chlorite was determined by means of electron microprobes: Superprobe JCXA-733, $\mathrm{U}=15 \mathrm{kV}, \mathrm{I}=15 \mathrm{nA}$ (the Mineralogical Institute of Russian Academy of Science, Russia); SEM JEOL JSM-35 with LINK QX2000 (the Department of Earth Sciences, Keele University, UK); Superprobe JEOL 8600 (Geological Institute, Aarhus University, Denmark); and Cameca $S X 100, \mathrm{U}=15 \mathrm{kV}$, $\mathrm{I}=10 \mathrm{nA}$, beam size $1 \mathrm{~mm}$ (Faculty of Geology, Warsaw University). Altogether 258 analyses of chlorite composition in 180 grains were conducted. 
Mineral phases were analysed using X-ray diffraction using a Geigerflex Rigaku Denki, CoK $\alpha$ radiation with Fe filter, $\mathrm{U}=30 \mathrm{kV}, \mathrm{I}=25 \mathrm{~mA}, \mathrm{tl}=2 \mathrm{~s}, \mathrm{ss}=0.02^{\circ}$ (University of Silesia, Poland). The presence of interstratifications or intergrowths within the chlorite crystals was investigated in two ways: (1) using Philips CM 20 high-resolution transmission electron microscopy (HRTEM) operated at $200 \mathrm{kV}$ with lattice image $1.4 \AA$, and (2) by XRD, chlorite from the vein in the Strzelin granite being separated, then powdered, oriented, glycolated and heated to $180^{\circ} \mathrm{C}$ and to $550^{\circ} \mathrm{C}$ for 2 hours.

\section{FORMS OF CHLORITE}

Chlorite in the granites investigated occurs in post-biotite and spherulitic forms (Figs. 1 and 2). The post-biotite chlorite, forming as a result of partial or entire replacement of the biotite, is termed a secondary hydrothermal mineral. The size of grains ranges from 0.1 to $1.5 \mathrm{~mm}$ (Fig. 2A, B, D-F). The localisation of particular types of chlorite within the granite depends on its origin.

Spherulitic chlorite forms smaller (ca. $0.05 \mathrm{~mm}$ ), radiant crystals. It crystallised in two possible ways:

- crystallisation from hydrothermal fluid in fractures, microfractures or intergranular spaces in granite as a primary hydrothermal mineral (Figs. 1 and 2C);

- replacement of post-biotite chlorite as a secondary hydrothermal mineral (Fig. 2D-F).

According to Janeczek (1983) this alteration consists in the dissolving of post-biotite chlorite and its recrystallisation in the presence of crystal nuclei.
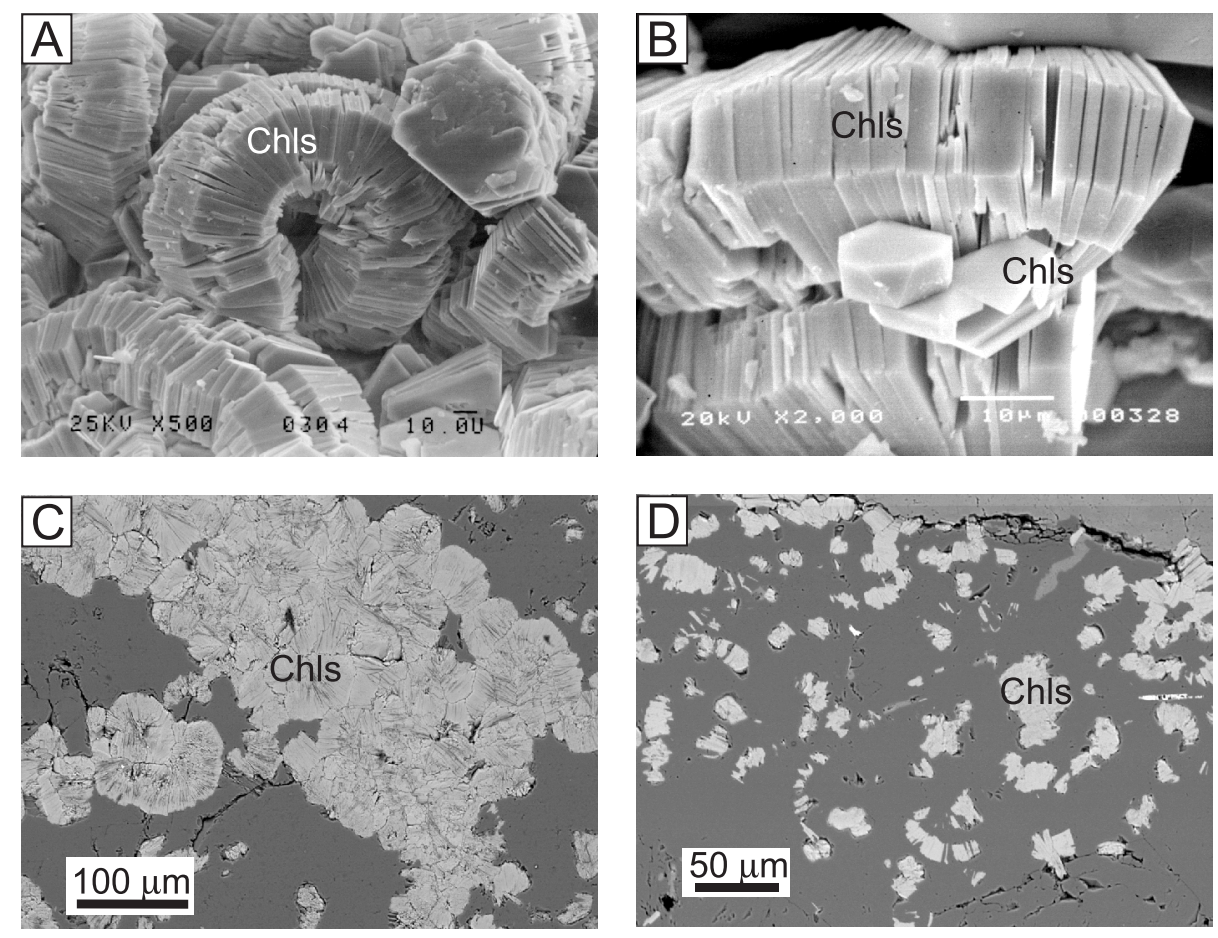
high, but chlorite is almost absent there. calcite (Ciesielczuk and Janeczek, 2004).
Both types of chlorite optically show pale green to creamy pleochroism and characteristic, subnormal, greyish-blue interference colours. Pleochroic colours of chlorites formed in the Borów granite are darker (green) than these from the Strzelin granite.

\section{SITES AND FREQUENCY OF CHLORITE WITHIN GRANITE}

Post-biotite chlorite is present even in unaltered granite. The process of replacement of biotite has been widely described (Veblen and Ferry, 1983; Olives-Baños and Amouric, 1984; Eggleton and Banfield, 1985; Parneix and Petit, 1991; Janeczek, 1994; Ciesielczuk, 2000b). The Strzelin granite contains up to a few per cent of chlorite, whereas the Borów granite contains less than 1\%.

Post-biotite chlorite is frequently found in the slightly altered Strzelin granite. In moderately altered granite its content decreases, while the content of spherulitic chlorite increases. It hardly ever occurs in strongly altered granites. Spherulitic chlorite is almost absent in unaltered granites. It is frequent in moderately and strongly altered ones, except in the bleached zones which surround hydrothermal veins. The width of these zones is approximately $0.5 \mathrm{~cm}$ and the degree of alteration is

Spherulitic chlorite is also frequent in hydrothermal veins. The fracture filling of the Strzelin granite is mainly polymineralic, where chlorite and quartz are the prevalent minerals. In the sequence of crystallisation chlorite crystallises at relatively high temperatures as the fourth mineral after quartz, feldspars and muscovite, and before clinozoisite, prehnite, laumontite/kaolinite and

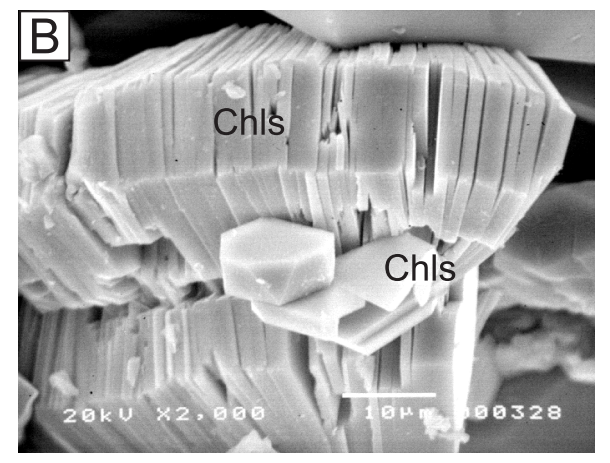

Fig. 1. Aggregates of spherulitic chlorite (Chls) present in hydrothermal veins in the Strzelin granite (A, B) and strongly altered Borów granite (C, D) 

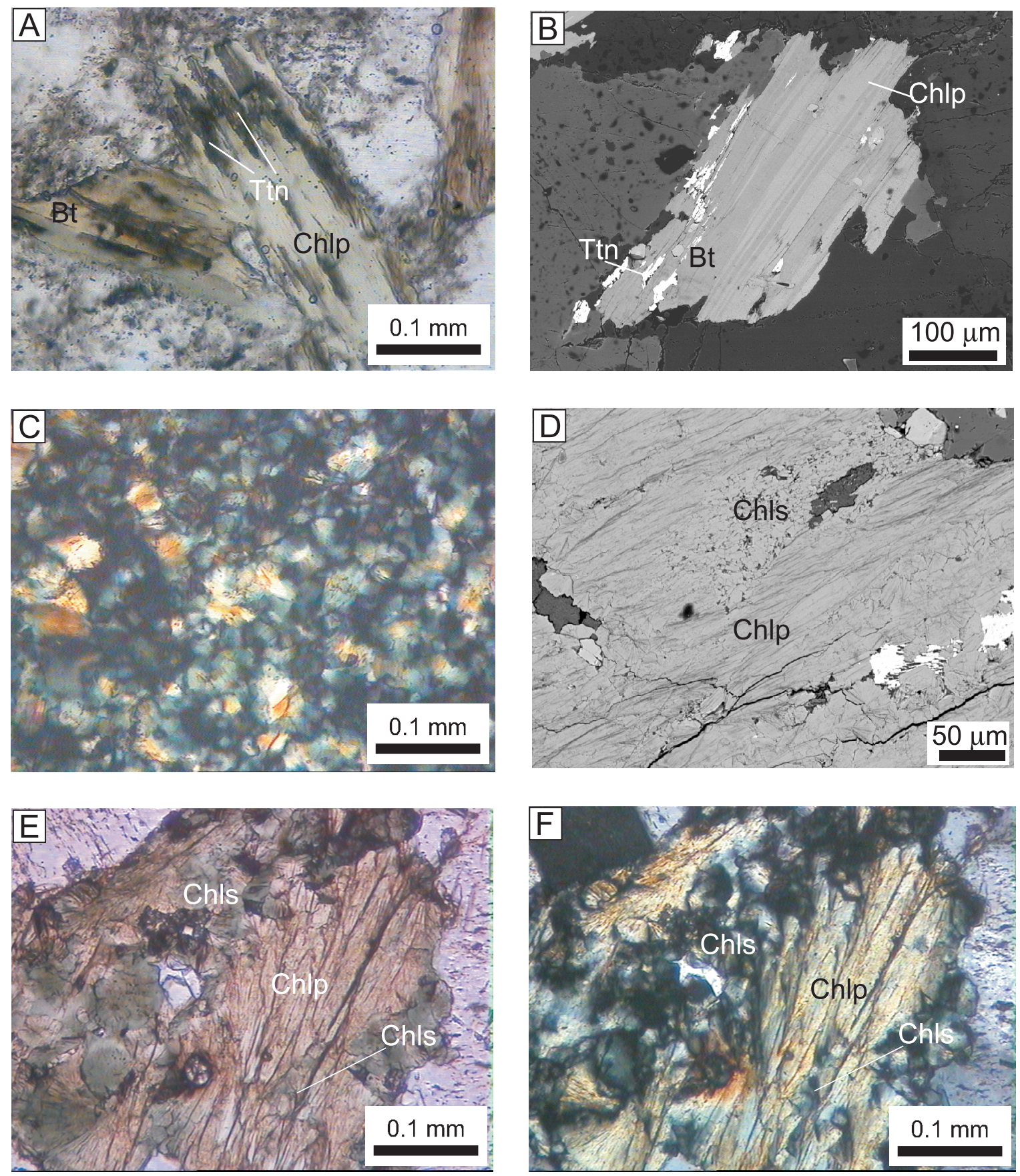

Fig. 2A, B - replacement of biotite (Bt) by post-biotite chlorite (Chlp), titanite (Ttn) seen in fracture planes; C - spherulitic chlorite; D-F - the replacement of post-biotite chlorite (Chlp) by spherulitic chlorite (Chls); the process of replacement starts along the grain boundaries and fracture planes

A, C, E, F - optical microscope images, A, E - plane polarized light; C, F - crossed polars; B, D - BSE images; A - strongly altered Strzelin granite; B - slightly altered Strzelin granite; C-F - strongly altered Borów granite

The hydrothermal veins in the Borów granite are mainly monomineralic, filled with quartz. Only certain narrow, wide veins up to $1 \mathrm{~cm}$ are polymineralic and consist of quartz, feldspars, spherulitic chlorite and fluorite.

\section{CHEMICAL COMPOSITION OF CHLORITE}

The chemical composition of the chlorite is shown on the chlorite classification diagram recommended by the Nomen- clature Committee of the AIPEA (Bailey, 1980; Fig. 3). Chlorite grains from the Strzelin granite contain $67 \%$ of chamosite particles (cha) $\left(\mathrm{Fe}_{5}^{2+} \mathrm{Al}\right)\left(\mathrm{Si}_{3} \mathrm{Al}\right) \mathrm{O}_{10}(\mathrm{OH})_{8}, 31 \%$ of clinochlore (cli) $\left(\mathrm{Mg}_{5} \mathrm{Al}\right)\left(\mathrm{Si}_{3} \mathrm{Al}\right) \mathrm{O}_{10}(\mathrm{OH})_{8}$ and $1 \%$ of pennantite (pen) $\left(\mathrm{Mn}_{5}^{2+} \mathrm{Al}\right)\left(\mathrm{Si}_{3} \mathrm{Al}\right) \mathrm{O}_{10}(\mathrm{OH})_{8}$ on average. Chlorite grains formed in unaltered granite contain $60-70 \%$ cha, $29-39 \%$ cli and $1-2 \%$ pen, chlorite grains from slightly altered granite contain $60-79 \%$ cha, $20-38 \%$ cli and $1-2 \%$ pen, and chlorites from strongly altered granite contain $61-73 \%$ cha, $25-37 \%$ cli and $1-3 \%$ pen. The composition of chlorites 


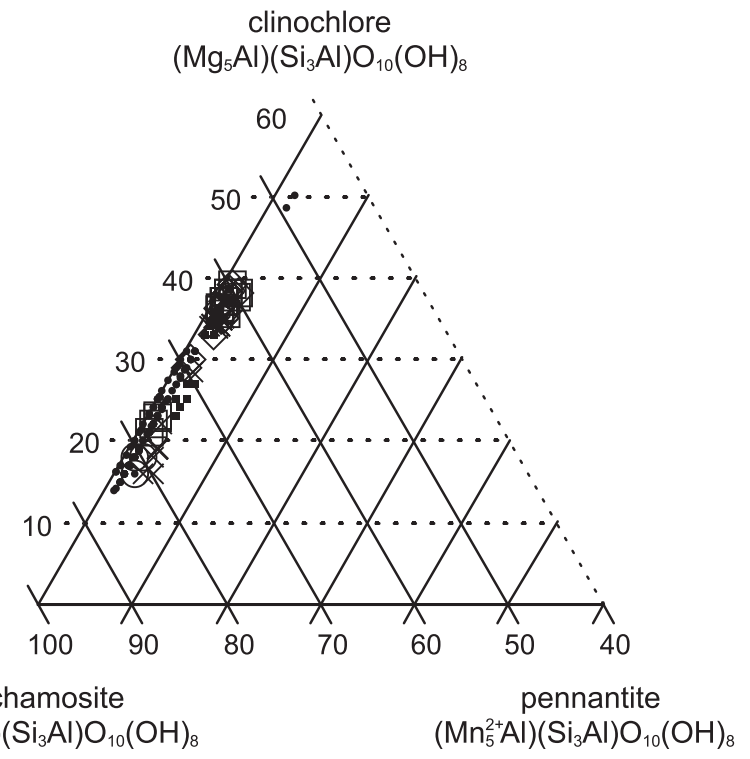

Fig. 3. Chemical composition of chlorites plotted on the clinochlore-pennantite-chamosite diagram

Chlorite from the Borów granite: unaltered (open circles), strongly altered (filled circles), and from the Strzelin granite: unaltered (open diamond), slightly altered (open square), strongly altered (filled square) and hydrothermal vein (cross)

formed in hydrothermal veins of the Strzelin granite ranges from 63 to $65 \%$ cha, from 34 to $35 \%$ cli and from 1 to $2 \%$ pen (Fig. 3). Chlorites from the Borów granite contain less magnesium but more iron, $76 \%$ of chamosite, $23 \%$ of clinochlore and $1 \%$ of pennantite on average. Chlorites formed in unaltered granite contain $80-82 \%$ cha, $16-18 \%$ cli and $1-2 \%$ pen, chlorites from the strongly altered granite contain $48-86 \%$ cha, $14-20 \%$ cli and $0-2 \%$ pen, chlorites formed in hydrothermal veins range from 63 to $64 \%$ cha, from 34 to $35 \%$ cli and from 1 to $2 \%$ pen (Fig. 3 ).

Microprobe analyses of chlorite of different shapes and formed in different parts of the Strzelin granite are shown in Table 1. Data in the first four columns show the variability of chlorite composition in the altered Strzelin granite up to the hydrothermal vein. The $\mathrm{Al}^{\mathrm{IV}}$ content increases towards the mineralisation zone $(1.25,1.28,1.29$ and 1.36 a.p.h.f.u. respectively). The next two columns show a similar average composition of the core and rim parts of chlorite grains, and the last two columns give the composition of post-biotite and spherulitic chlorite formed within the Strzelin granite. Microprobe analyses of chlorite of different shapes and formed in different parts of the Borów granite are shown in Table 2. Since hydrothermal alteration in the shear zone in Borów was multistadial and complex, progressive alteration has not been observed. The various averaged chemical compositions of chlorite grains in five macroscopically and microscopically different samples of strongly altered Borów granite is shown in columns 2-6 and the mean value is given in column 7 . Chlorite crystallised in hydrothermal veins contains the highest $\mathrm{Fe}_{\text {tot }}$ and $\mathrm{Al}^{\mathrm{IV}}$ content. The chemical compositions of cores and rims of chlorite grains are also similar to those of chlorites of post-biotite and spherulitic forms. Chlorites from the Borów granite are more ferrugineous than those from the Strzelin granite. These data are consistent with the results of research of Janeczek $(1983,1985)$ in the Strzegom-Sobótka Massif. This author observed a similar chemical composition of all chlorites present in pegmatites and granitoids in different parts of the massif.

Major cation relationships in the chlorite grains investigated are shown in Figure 4. The relationship between Fe and $\mathrm{Mg}$ shows a simple linear correlation with a negative slope and a correlation coefficient of 0.80 (Fig. 4A). But there is no correlation between $\mathrm{Mg}$ content with respect to $\mathrm{Al}^{\mathrm{IV}}$ or $\mathrm{Al}^{\mathrm{VI}}$ (Fig. 4B, C) and $\mathrm{Al}^{\mathrm{IV}}$ versus $\mathrm{Al}^{\mathrm{VI}}$ (Fig. 4D).

The ratio $\mathrm{Fe} /(\mathrm{Fe}+\mathrm{Mg})$ in all the grains of chlorite investigated is relatively high, and ranges from 0.64 to 0.70 for the Strzelin granite and from 0.68 to 0.84 for the Borów granite. The $\mathrm{Al}^{\mathrm{IV}} /\left(\mathrm{Si}+\mathrm{Al}^{\mathrm{IV}}\right)$ ratio ranges from 0.30 to 0.35 for the Strzelin granite and from 0.29 to 0.34 for the Borów granite (Tables 1 and 2; Fig. 5; Ciesielczuk, 2000b). The relations of the tetrahedral $\mathrm{Al}$ to $\mathrm{Si}: \mathrm{Al}^{\mathrm{IV}} /\left(\mathrm{Si}+\mathrm{Al}^{\mathrm{IV}}\right)$ versus octahedral sheet composition expressed by $\mathrm{Fe} /(\mathrm{Fe}+\mathrm{Mg})$ in chlorite grains investigated is shown in Figure 5. All points are grouped more or less together and these points do not show any mutual dependence.

\section{PURITY OF CHLORITE}

The presence of intergrown phases within chlorite sheets was postulated by Olives-Baños and Amouric (1984), Jiang et al. (1994), Xu and Veblen (1996) and other authors. Chlorite can be contaminated by kaolinite or interstratified with berthierine or smectite, which eliminates the mineral composition as a basis for geothermometer calculation.

In the cases examined presence of smectite can be neglected as the sum of $\mathrm{CaO}+\mathrm{Na}_{2} \mathrm{O}+\mathrm{K}_{2} \mathrm{O}$ in all analyses is lower than 0.3 wt.\%. Moreover, Table 3 shows XRD data for chlorite formed in the hydrothermal vein and the strongly altered Strzelin granite. The XRD patterns are almost identical, and match the chamosite Ib pattern (ASTM 13-0029). For the purpose of detection of chlorite in the hydrothermal vein the sample was (1) sedimented, oriented, air-dried, (2) glycolated and (3) heated to $180^{\circ} \mathrm{C}$ for 2 hours and (4) to $550^{\circ} \mathrm{C}$ for 2 hours (Fig. 6). After saturation of the chlorite with ethylene glycol the $14.15 \AA$ peak (001) stayed at the same position, which means, that there are no swelling interlayers. Heated to $180^{\circ} \mathrm{C}$ the chlorite sample faded, but the peak positions stayed the same. The sample of chlorite heated to $550^{\circ} \mathrm{C}$ turned brownish and peak positions and intensities changed. The (001) peak moved to $13.98 \AA$ with maximum intensity, which means that the hydroxyl group was removed from the chlorite structure. This chlorite treatment demonstrated the absence of mixed layer minerals involving swelling phases, so it can be concluded that the chlorite is pure at the detection level of the XRD method.

Hence, high-resolution transmission electron microscopy (HRTEM) was applied. The post-biotite chlorite from unaltered and slightly altered Strzelin granite shows no signs of the 
Averaged microprobe analyses of chlorite formed in the Strzelin granite, structural formulae calculated on the basis of 140, and values of chlorite formation temperatures calculated on the basis of the Cathelineau (1988) and the Kranidiotis and MacLean (1987) methods

\begin{tabular}{|c|c|c|c|c|c|c|c|c|}
\hline $\begin{array}{c}\text { Chlorite } \\
\text { location/shape }\end{array}$ & $\begin{array}{c}\text { Unaltered } \\
\text { granite }\end{array}$ & $\begin{array}{l}\text { Slightly al- } \\
\text { tered granite }\end{array}$ & $\begin{array}{c}\text { Strongly altered } \\
\text { granite }\end{array}$ & $\begin{array}{c}\text { Hydrothermal } \\
\text { vein }\end{array}$ & Rim & Core & $\begin{array}{c}\text { Post-biotite } \\
\text { chlorite }\end{array}$ & $\begin{array}{c}\text { Spherulitic } \\
\text { chlorite }\end{array}$ \\
\hline $\begin{array}{l}\text { Number of } \\
\text { analyses }\end{array}$ & 9 & 34 & 29 & 21 & 17 & 15 & 25 & 17 \\
\hline $\mathrm{SiO}_{2}$ & 25.25 & 24.60 & 24.80 & 24.23 & 24.67 & 24.70 & 24.75 & 24.11 \\
\hline $\mathrm{TiO}_{2}$ & 0.04 & 0.14 & 0.10 & 0.02 & 0.11 & 0.12 & 0.08 & 0.03 \\
\hline $\mathrm{Al}_{2} \mathrm{O}_{3}$ & 21.08 & 19.74 & 20.42 & 21.51 & 19.97 & 20.06 & 20.31 & 21.83 \\
\hline $\mathrm{FeO}_{\text {tot }}$ & 31.49 & 34.88 & 32.52 & 31.86 & 33.91 & 33.53 & 32.54 & 32.99 \\
\hline $\mathrm{MnO}$ & 0.81 & 0.60 & 0.86 & 0.78 & 0.66 & 0.69 & 0.67 & 0.90 \\
\hline $\mathrm{MgO}$ & 10.43 & 8.27 & 9.47 & 9.66 & 8.81 & 9.13 & 9.61 & 9.04 \\
\hline $\mathrm{Cr}_{2} \mathrm{O}_{3}$ & 0.02 & 0.02 & 0.02 & 0.01 & 0.02 & 0.02 & 0.02 & 0.01 \\
\hline $\mathrm{NiO}$ & 0.02 & 0.03 & 0.01 & 0.04 & 0.03 & 0.01 & 0.02 & 0.05 \\
\hline $\mathrm{CaO}$ & 0.11 & 0.06 & 0.10 & 0.17 & 0.07 & 0.06 & 0.12 & 0.14 \\
\hline $\mathrm{Na}_{2} \mathrm{O}$ & 0.01 & 0.01 & 0.01 & 0.01 & 0.01 & 0.01 & 0.02 & 0.02 \\
\hline $\mathrm{K}_{2} \mathrm{O}$ & 0.02 & 0.09 & 0.01 & 0.00 & 0.04 & 0.07 & 0.05 & 0.00 \\
\hline $\mathrm{H}_{2} \mathrm{O}$ & 11.00 & 10.83 & 10.95 & 11.01 & 10.88 & 10.92 & 10.95 & 10.96 \\
\hline Total & 99.08 & 99.26 & 99.26 & 99.31 & 99.18 & 99.33 & 99.13 & 100.06 \\
\hline cha $\%$ & 63 & 70 & 65 & 64 & 68 & 66 & 65 & 66 \\
\hline cli $\%$ & 36 & 29 & 33 & 34 & 31 & 33 & 34 & 32 \\
\hline pen $\%$ & 1 & 1 & 2 & 2 & 1 & 1 & 1 & 2 \\
\hline $\mathrm{Si}$ & 2.75 & 2.72 & 2.70 & 2.64 & 2.72 & 2.71 & 2.71 & 2.60 \\
\hline $\mathrm{Al}^{\mathrm{IV}}$ & 1.25 & 1.28 & 1.29 & 1.36 & 1.28 & 1.29 & 1.29 & 1.40 \\
\hline Site T & 4 & 4 & 4 & 4 & 4 & 4 & 4 & 4 \\
\hline $\mathrm{Al}^{\mathrm{VI}}$ & 1.30 & 1.30 & 1.33 & 1.40 & 1.31 & 1.31 & 1.33 & 1.38 \\
\hline $\mathrm{Ti}$ & 0.01 & 0.01 & 0.01 & 0.00 & 0.01 & 0.01 & 0.01 & 0.00 \\
\hline $\mathrm{Fe}_{\text {tot }}$ & 2.87 & 3.24 & 2.99 & 2.90 & 3.13 & 3.08 & 2.98 & 3.05 \\
\hline $\mathrm{Mn}$ & 0.07 & 0.06 & 0.08 & 0.07 & 0.06 & 0.06 & 0.06 & 0.08 \\
\hline $\mathrm{Mg}$ & 1.69 & 1.36 & 1.54 & 1.57 & 1.44 & 1.49 & 1.57 & 1.46 \\
\hline $\mathrm{Cr}$ & 0.00 & 0.00 & 0.00 & 0.00 & 0.00 & 0.00 & 0.00 & 0.00 \\
\hline $\mathrm{Ni}$ & 0.00 & 0.00 & 0.00 & 0.00 & 0.00 & 0.00 & 0.00 & 0.00 \\
\hline $\mathrm{Ca}$ & 0.01 & 0.01 & 0.01 & 0.02 & 0.01 & 0.01 & 0.01 & 0.02 \\
\hline $\mathrm{Na}$ & 0.00 & 0.00 & 0.00 & 0.00 & 0.00 & 0.00 & 0.00 & 0.01 \\
\hline $\mathrm{K}$ & 0.00 & 0.01 & 0.00 & 0.00 & 0.01 & 0.01 & 0.01 & 0.00 \\
\hline Site $\mathrm{O}$ & 5.97 & 5.99 & 5.97 & 5.98 & 5.98 & 5.98 & 5.98 & 6.00 \\
\hline $\mathrm{Fe} /(\mathrm{Fe}+\mathrm{Mg})$ & 0.63 & 0.70 & 0.66 & 0.65 & 0.68 & 0.67 & 0.66 & 0.68 \\
\hline $\mathrm{Al}^{\mathrm{IV}} /\left(\mathrm{Si}+\mathrm{Al}^{\mathrm{IV}}\right)$ & 0.31 & 0.32 & 0.32 & 0.34 & 0.32 & 0.32 & 0.32 & 0.35 \\
\hline$T\left[{ }^{0} \mathrm{C}\right]^{1}$ & 334 & 349 & 355 & 376 & 351 & 352 & 354 & 388 \\
\hline$T\left[{ }^{0} \mathrm{C}\right]^{2}$ & 326 & 341 & 342 & 355 & 340 & 341 & 340 & 364 \\
\hline
\end{tabular}

tot - total iron content as FeO; nd - not determined; ${ }^{1}$ - temperature calculated on the basis of the Cathelineau (1988) method ${ }^{2}$ - temperature calculated on the basis of the Kranidiotis and MacLean (1987) method

presence of interstratification or intergrowths of other minerals within the chlorite crystals (Fig. 7).

\section{RELATIONSHIP BETWEEN CHLORITE AND ROCK COMPOSITION}

Xie et al. (1997) showed a high correlation between the $\mathrm{MgO}$ content in chlorite and that in the host rock. Cathelineau and Nieva (1985) and Shikazono and Kawahata (1987) suggested that the iron and magnesium content in chlorite depends on the iron and magnesium content in the host, unaltered rock.
On the diagrams of $\mathrm{MgO} / \mathrm{FeO}$ in chlorite versus $\mathrm{MgO} / \mathrm{FeO}$ in unaltered rock, created on the basis of examples derived from volcanic rocks from different localities, all points lie close to a 1:1 line. A few points outside this line were interpreted as the effect of the influence of additional factors, such as the $\mathrm{MgO} / \mathrm{FeO}$ content of hydrothermal fluid.

The $\mathrm{MgO}$ content in the unaltered Strzelin granite is $0.7 \%$ (Bereś, 1969) or 0.8\% (Ciesielczuk, 2000b). The Borów granite contains $0.47,0.63 \%$ (Majerowicz, 1972) and $0.19 \%$ (Ciesielczuk, 2000b) of $\mathrm{MgO}$. This means that the $\mathrm{MgO}$ content in the Strzelin granite is slightly higher than that in the Borów granite. A similar relationship was found for the $\mathrm{MgO}$ content in 
$\mathrm{T}$ a b 1 e 2

Averaged microprobe analyses of chlorite formed in the Borów granite, structural formulae calculated on the basis of 140, and values of chlorite formation temperatures calculated on the basis of the Cathelineau (1988) and the Kranidiotis and MacLean (1987) methods

\begin{tabular}{|c|c|c|c|c|c|c|c|c|c|c|c|c|}
\hline $\begin{array}{c}\text { Chlorite } \\
\text { location/shape }\end{array}$ & $\begin{array}{l}\text { Unal- } \\
\text { tered } \\
\text { granite }\end{array}$ & $\begin{array}{l}\text { Strongly } \\
\text { altered } \\
835\end{array}$ & $\begin{array}{l}\text { Strongly } \\
\text { altered } \\
833\end{array}$ & $\begin{array}{c}\text { Strongly } \\
\text { altered } \\
846 / 5 \\
\end{array}$ & $\begin{array}{l}\text { Strongly } \\
\text { altered } \\
838\end{array}$ & $\begin{array}{l}\text { Strongly } \\
\text { altered } \\
842\end{array}$ & $\begin{array}{l}\text { Strongly } \\
\text { altered } \\
\text { average }\end{array}$ & $\begin{array}{c}\text { Hydro- } \\
\text { thermal } \\
\text { vein }\end{array}$ & Rim & Core & $\begin{array}{l}\text { Post-biotite } \\
\text { chlorite }\end{array}$ & $\begin{array}{l}\text { Spherulitic } \\
\text { chlorite }\end{array}$ \\
\hline $\begin{array}{c}\text { Number of } \\
\text { analyses }\end{array}$ & 8 & 14 & 21 & 29 & 39 & 22 & 125 & 12 & 24 & 25 & 64 & 46 \\
\hline $\mathrm{SiO}_{2}$ & 24.05 & 25.57 & 24.73 & 23.40 & 24.55 & 24.76 & 24.60 & 22.92 & 24.92 & 24.72 & 24.45 & 24.30 \\
\hline $\mathrm{TiO}_{2}$ & 0.04 & 0.04 & 0.04 & 0.04 & 0.03 & 0.26 & 0.08 & 0.04 & 0.04 & 0.05 & 0.04 & 0.04 \\
\hline $\mathrm{Al}_{2} \mathrm{O}_{3}$ & 18.49 & 17.98 & 19.27 & 19.18 & 19.25 & 18.84 & 18.91 & 19.75 & 19.14 & 18.90 & 19.55 & 19.50 \\
\hline $\mathrm{FeO}_{\text {tot }}$ & 40.01 & 34.91 & 37.18 & 40.59 & 37.56 & 38.64 & 37.78 & 41.11 & 35.83 & 36.61 & 36.48 & 36.73 \\
\hline $\mathrm{MnO}$ & 0.74 & 0.39 & 0.40 & 0.33 & 0.29 & 0.26 & 0.34 & 0.33 & 0.42 & 0.44 & 0.44 & 0.44 \\
\hline $\mathrm{MgO}$ & 5.09 & 9.41 & 6.76 & 4.94 & 6.37 & 5.28 & 6.55 & 4.37 & 7.82 & 7.74 & 7.21 & 7.19 \\
\hline $\mathrm{Cr}_{2} \mathrm{O}_{3}$ & nd & 0.01 & 0.01 & 0.01 & 0.02 & nd & 0.01 & 0.02 & 0.02 & 0.01 & 0.01 & 0.01 \\
\hline $\mathrm{NiO}$ & nd & 0.02 & 0.03 & 0.03 & 0.02 & nd & 0.02 & 0.01 & 0.03 & 0.03 & 0.02 & 0.03 \\
\hline $\mathrm{CaO}$ & 0.08 & 0.02 & 0.05 & 0.01 & 0.07 & 0.26 & 0.08 & 0.01 & 0.04 & 0.04 & 0.06 & 0.05 \\
\hline $\mathrm{Na}_{2} \mathrm{O}$ & 0.01 & 0.00 & 0.01 & 0.01 & 0.01 & 0.10 & 0.03 & 0.01 & 0.01 & 0.01 & 0.01 & 0.01 \\
\hline $\mathrm{K}_{2} \mathrm{O}$ & 0.02 & 0.00 & 0.01 & 0.02 & 0.01 & 0.14 & 0.03 & 0.01 & 0.01 & 0.01 & 0.02 & 0.01 \\
\hline $\mathrm{H}_{2} \mathrm{O}$ & 10.61 & 10.84 & 10.73 & 10.49 & 10.66 & 10.72 & 10.69 & 10.46 & 10.78 & 10.75 & 10.73 & 10.71 \\
\hline Total & 99.14 & 99.20 & 99.22 & 99.00 & 98.84 & 99.25 & 99.11 & 99.03 & 99.04 & 99.30 & 99.02 & 99.02 \\
\hline cha $\%$ & 80 & 67 & 75 & 81 & 76 & 80 & 76 & 83 & 71 & 72 & 73 & 74 \\
\hline cli $\%$ & 18 & 32 & 24 & 18 & 23 & 19 & 23 & 16 & 28 & 27 & 26 & 25 \\
\hline pen $\%$ & 2 & 1 & 1 & 1 & 1 & 1 & 1 & 1 & 1 & 1 & 1 & 1 \\
\hline $\mathrm{Si}$ & 2.75 & 2.83 & 2.76 & 2.67 & 2.76 & 2.80 & 2.76 & 2.63 & 2.77 & 2.76 & 2.73 & 2.72 \\
\hline $\mathrm{Al}^{\mathrm{IV}}$ & 1.25 & 1.17 & 1.24 & 1.33 & 1.24 & 1.21 & 1.24 & 1.37 & 1.23 & 1.24 & 1.27 & 1.28 \\
\hline Site $T$ & 4 & 4 & 4 & 4 & 4 & 4 & 4 & 4 & 4 & 4 & 4 & 4 \\
\hline $\mathrm{Al}^{\mathrm{VI}}$ & 1.23 & 1.17 & 1.30 & 1.25 & 1.31 & 1.30 & 1.27 & 1.30 & 1.28 & 1.24 & 1.31 & 1.29 \\
\hline $\mathrm{Ti}$ & 0.00 & 0.00 & 0.00 & 0.00 & 0.00 & 0.02 & 0.01 & 0.00 & 0.00 & 0.00 & 0.00 & 0.00 \\
\hline $\mathrm{Fe}_{\text {tot }}$ & 3.82 & 3.23 & 3.48 & 3.90 & 3.54 & 3.65 & 3.56 & 3.94 & 3.34 & 3.42 & 3.42 & 3.45 \\
\hline $\mathrm{Mn}$ & 0.07 & 0.04 & 0.04 & 0.03 & 0.03 & 0.03 & 0.03 & 0.03 & 0.04 & 0.04 & 0.04 & 0.04 \\
\hline $\mathrm{Mg}$ & 0.87 & 1.55 & 1.13 & 0.84 & 1.07 & 0.89 & 1.09 & 0.75 & 1.29 & 1.28 & 1.19 & 1.19 \\
\hline $\mathrm{Cr}$ & nd & 0.00 & 0.00 & 0.00 & 0.00 & nd & 0.00 & 0.00 & 0.00 & 0.00 & 0.00 & 0.00 \\
\hline $\mathrm{Ni}$ & nd & 0.00 & 0.00 & 0.00 & 0.00 & nd & 0.00 & 0.00 & 0.00 & 0.00 & 0.00 & 0.00 \\
\hline $\mathrm{Ca}$ & 0.01 & 0.00 & 0.01 & 0.01 & 0.01 & 0.03 & 0.01 & 0.00 & 0.00 & 0.01 & 0.01 & 0.01 \\
\hline $\mathrm{Na}$ & 0.00 & 0.00 & 0.00 & 0.00 & 0.00 & 0.02 & 0.01 & 0.00 & 0.00 & 0.00 & 0.00 & 0.00 \\
\hline $\mathrm{K}$ & 0.00 & 0.00 & 0.00 & 0.00 & 0.00 & 0.02 & 0.01 & 0.00 & 0.00 & 0.00 & 0.00 & 0.00 \\
\hline Site $O$ & 6.00 & 6.00 & 5.96 & 6.04 & 5.96 & 5.95 & 5.98 & 6.03 & 5.97 & 6.00 & 5.98 & 5.99 \\
\hline $\mathrm{Fe} /(\mathrm{Fe}+\mathrm{Mg})$ & 0.81 & 0.68 & 0.76 & 0.82 & 0.77 & 0.80 & 0.76 & 0.84 & 0.72 & 0.73 & 0.74 & 0.74 \\
\hline $\mathrm{Al}^{\mathrm{IV}} /\left(\mathrm{Si}+\mathrm{Al}^{\mathrm{IV}}\right)$ & 0.31 & 0.29 & 0.31 & 0.33 & 0.31 & 0.30 & 0.31 & 0.34 & 0.31 & 0.31 & 0.32 & 0.32 \\
\hline$T\left[{ }^{0} \mathrm{C}\right]^{1}$ & 341 & 316 & 336 & 366 & 337 & 326 & 336 & 379 & 333 & 339 & 346 & 350 \\
\hline$T\left[{ }^{0} \mathrm{C}\right]^{2}$ & 343 & 317 & 336 & 361 & 338 & 333 & 337 & 371 & 332 & 336 & 342 & 344 \\
\hline
\end{tabular}

Explanations as in Table 1

the chlorites: chlorite grains formed within the Strzelin granite contain more $\mathrm{MgO}$ than the chlorite from the Borów granite (Tables 1 and 2). Therefore the lower content of magnesium in chlorites formed in the Borów granite can be related to the lower content of magnesium in the host rock. The $\mathrm{MgO} / \mathrm{FeO}$ ratio in chlorite and the $\mathrm{MgO} / \mathrm{FeO}$ ratio in unaltered Strzelin granite ( 0.32 and 0.3 respectively) and in unaltered Borów granite $(0.13$ and 0.08 respectively) lie very close to the $1: 1$ line supporting the linear dependence suggested by Cathelineau and Nieva (1985) and Shikazono and Kawahata (1987).

\section{CHLORITE AS A GEOTHERMOMETER}

Chlorite is frequently used as a geothermometer as its structure and chemical composition can reflect the physicochemical conditions of its formation. Shikazono and Kawahata (1987) found that the $\mathrm{Fe}^{2+} /\left(\mathrm{Fe}^{2+}+\mathrm{Mg}\right)$ ratio differs for chlorites formed in different hydrothermal environments. Moreover, they showed that the iron content in chlorite is temperature-related. De Caritat et al. (1993), Cathelineau and Nieva (1985), Kranidiotis and MacLean (1987), Zang and Fyfe (1995) and other authors systematically investigated the interdependence 

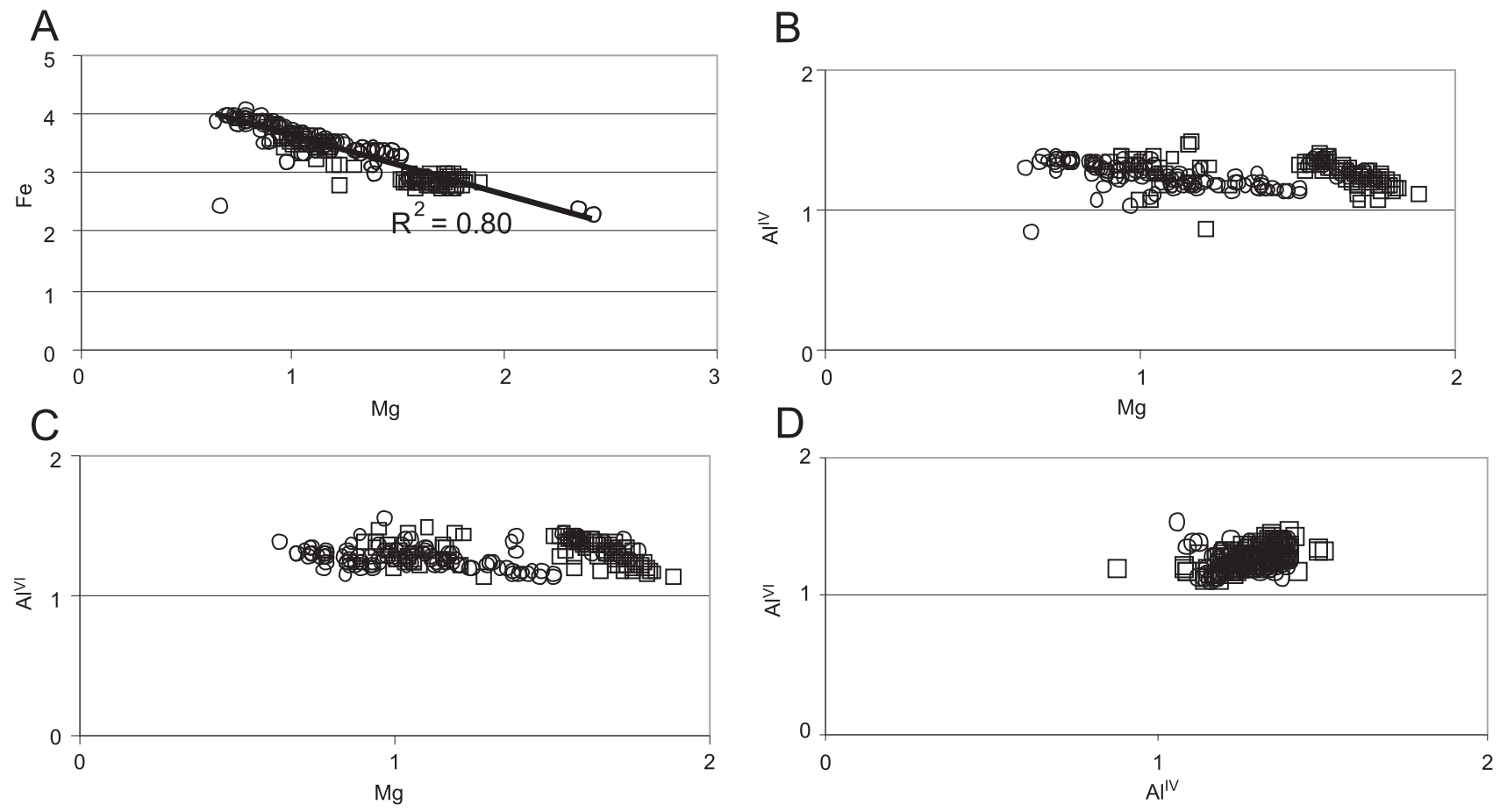

Fig. 4. Scatter diagrams of $\mathrm{A}-\mathrm{Fe}$ plotted against $\mathrm{Mg} ; \mathrm{B}-\mathrm{Al}^{\mathrm{IV}}$ versus $\mathrm{Mg} ; \mathrm{C}-\mathrm{Al}^{\mathrm{VI}}$ versus $\mathrm{Mg}$;

$\mathrm{D}-\mathrm{Al}^{\mathrm{VI}}$ versus $\mathrm{Al}^{\mathrm{IV}}$ (atoms per half formula unit) in chlorite from the Strzelin (squares) and Borów (circles) granites

T a b l e 3

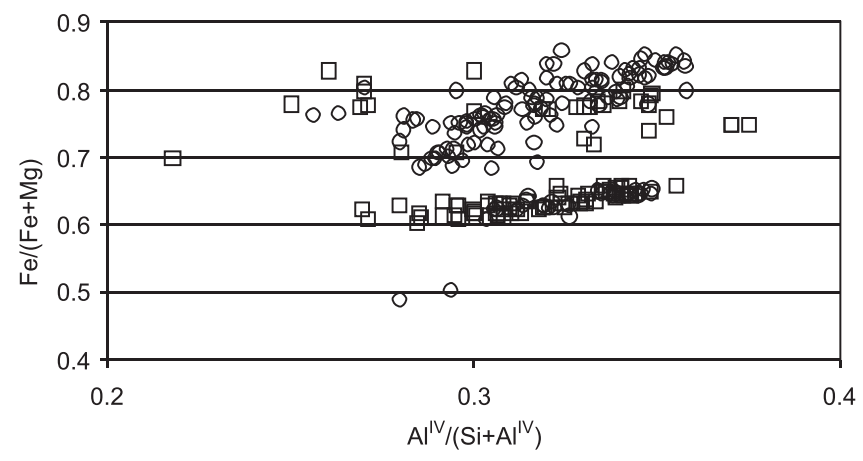

Fig. 5. Diagram of the relations of $\mathrm{Fe}^{2+} /\left(\mathrm{Fe}^{2+}+\mathrm{Mg}\right)$ versus $\mathrm{Al}^{\mathrm{IV}} /\left(\mathrm{Si}+\mathrm{Al}^{\mathrm{IV}}\right)$ in chlorites from the Strzelin (squares) and Borów (circles) granites

between chlorite composition and temperature. They claim that the effects of increasing intensity of hydrothermal alteration upon chlorite composition include a decrease in $\mathrm{Si}^{\mathrm{IV}}, \mathrm{Al}^{\mathrm{VI}}$ and structural vacancies in octahedral sites, and an increase in $\mathrm{Al}^{\mathrm{IV}}$, $\mathrm{Fe} /(\mathrm{Fe}+\mathrm{Mg})$ ratio, and the sum of cations in octahedral sites $\Sigma^{\mathrm{VI}}$. Kranidiotis and MacLean (1987) calibrated the geothermometer for chlorites formed in hydrothermal environments saturated in $\mathrm{Al}$, and thus in the presence of other Al-minerals. Jowett (1991, vide de Caritat et al., 1993) proposed the geothermometer $\left(T\left[{ }^{\circ} \mathrm{C}\right]=319 \mathrm{Al}_{\mathrm{c}}^{\mathrm{IV}}-69\right.$ with a corrected $\mathrm{Al}^{\mathrm{IV}}$ value of $\left.\mathrm{Al}_{\mathrm{c}}^{\mathrm{IV}}=\mathrm{Al}^{\mathrm{IV}}+0.1 \mathrm{Fe} /(\mathrm{Fe}+\mathrm{Mg})\right)$, which can be used for chlorites formed in different environments, but in the temperature interval of $150-325^{\circ} \mathrm{C}$ with a $\mathrm{Fe} /(\mathrm{Fe}+\mathrm{Mg})$ ratio less than 0.6. Vidal et al. (2001) proposed a four-thermodynamic-component solid solution model that accounts for the Tschermak, $\mathrm{Fe}-\mathrm{Mg}$, and di/trioctahedral substitutions for aluminous
XRD data of chlorite formed in the hydrothermal veins and strongly altered zones of the Strzelin granite

\begin{tabular}{|c|c|c|c|}
\hline \multicolumn{2}{|c|}{ Hydrothermal vein } & \multicolumn{2}{c|}{ Strongly altered granite } \\
\hline $\mathrm{d}(\AA)$ & $\mathrm{I}$ & $\mathrm{d}(\AA)$ & $\mathrm{I}$ \\
\hline 14.20 & 40 & 14.15 & 30 \\
\hline 7.08 & 100 & 7.06 & 100 \\
\hline 4.71 & 40 & 4.72 & 40 \\
\hline 3.535 & 60 & 3.536 & 50 \\
\hline 2.823 & 30 & 2.828 & 20 \\
\hline 2.607 & 20 & 2.610 & 8 \\
\hline 2.563 & 5 & 2.568 & 7 \\
\hline 2.457 & 10 & 2.458 & 8 \\
\hline 2.397 & 7 & 2.399 & 8 \\
\hline 2.272 & 10 & 2.270 & 7 \\
\hline 2.011 & 10 & 2.015 & 10 \\
\hline & & 1.891 & 5 \\
\hline 1.887 & 6 & 1.884 & 5 \\
\hline 1.825 & 4 & 1.828 & 2 \\
\hline 1.715 & 5 & & \\
\hline 1.658 & 4 & 1.666 & 2 \\
\hline 1.566 & 10 & 1.567 & 8 \\
\hline 1.540 & 30 & 1.554 & 5 \\
\hline 1.515 & 2 & 1.518 & 2 \\
\hline
\end{tabular}

( $\mathrm{Si}<3$ a.p.h.f.u.) chlorite in quartz-bearing rocks. They calibrated the relevant thermodynamic data with independent sets of published experiments and natural data. A modification of the geothermometer, applicable to low-T chlorites, was proposed by Inoue et al. (2009). They showed that low-temperature chlorites have generally higher contents of Si and larger 

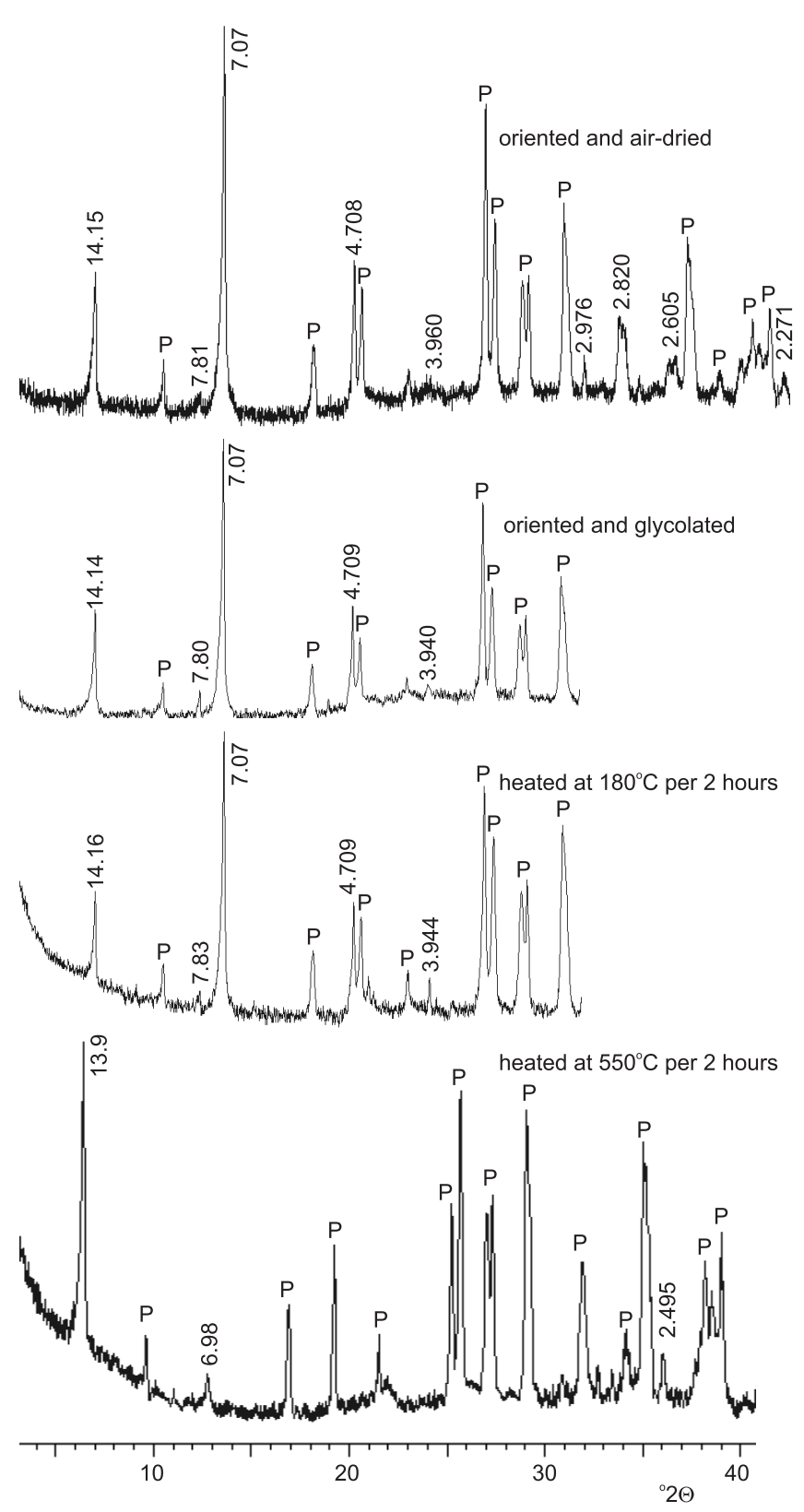

Fig. 6. XRD patterns of spherulitic chlorite formed in a hydrothermal vein in the Strzelin granite

$$
\mathrm{P} \text { - prehnite peaks }
$$

numbers of octahedral vacancies and lower contents of $\mathrm{Fe}+\mathrm{Mg}$ than higher-grade metamorphic chlorites. However, it is necessary to distinguish between $\mathrm{Fe}^{2+}$ and $\mathrm{Fe}^{3+}$, which is usually done by means of the Mössbauer spectroscopic method. The assumption that all iron is regarded as $\mathrm{Fe}^{2+}$ can lead to overestimation of temperature formation.

Taking into account chemical composition of chlorites formed in the Strzelin and Borów granites and restrictions of the proposed geothermometers, the following regression equations of establishing temperature $T\left({ }^{\circ} \mathrm{C}\right)$ for chlorites formed under hydrothermal environments were used:

$$
T=-61.92+321.98 \mathrm{Al}^{\mathrm{IV}}(\text { Cathelineau, 1988) }
$$

A
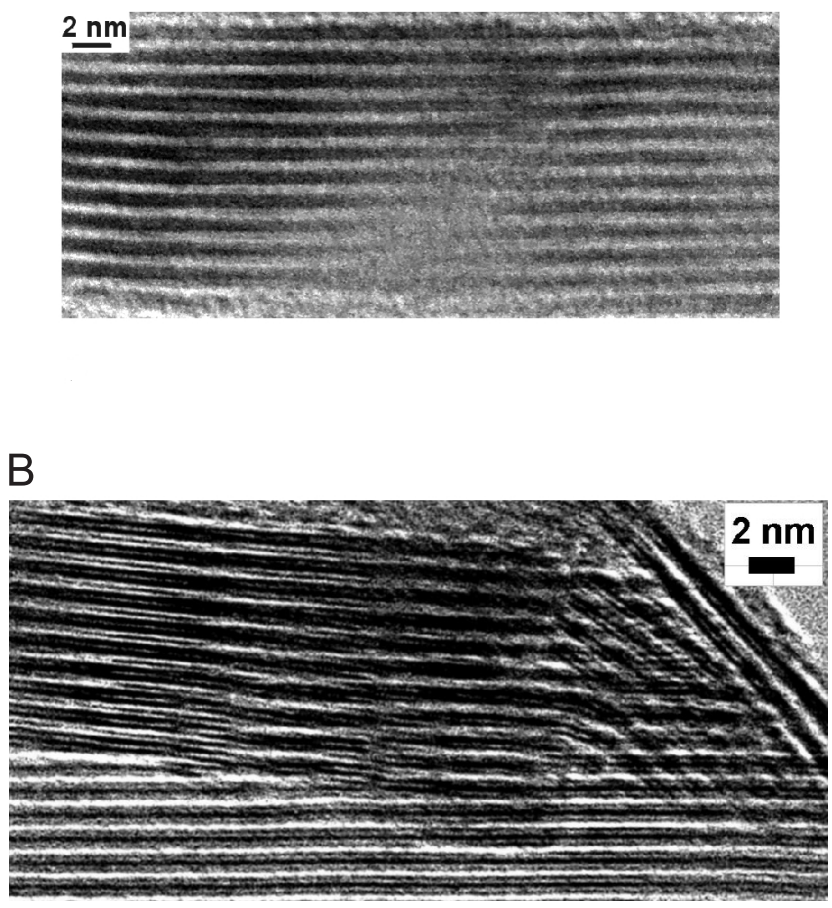

Fig. 7. A HRTEM image of chlorite with 14 Å periodicity

A - post-biotite chlorite formed in the unaltered Strzelin granite; B post-biotite chlorite crystallised in the slightly altered Strzelin granite

$$
\begin{gathered}
T=106 \mathrm{Al}_{\mathrm{c}}^{\mathrm{IV}}+18, \text { corrected } \mathrm{Al}^{\mathrm{IV}} \text { value } \\
\mathrm{Al}_{\mathrm{c}}^{\mathrm{IV}}=\mathrm{Al}^{\mathrm{IV}}+0.7 \mathrm{Fe} /(\mathrm{Fe}+\mathrm{Mg}) \\
\text { (Kranidiotis and MacLean, 1987) }
\end{gathered}
$$

Both methods reveal some interdependences between hydrothermal chlorite composition and the temperature of its formation. The inaccuracy of the Cathelieau (1988) geothermometer is $\pm 25^{\circ} \mathrm{C}$ and some results are within the limit of error of the method but the tendency is the same for chlorites from both granites. The equation proposed by Kranidiotis and MacLean (1987), considering the influence of $\mathrm{Fe}$ and $\mathrm{Mg}$ amount on temperature formation, seems to be more suitable, particularly in that the chlorite formed in the Borów granite contains more Fe and less $\mathrm{Mg}$ than that in the Strzelin granite. According to this geothermometer the differences between calculated temperatures are smaller.

Averaged calculated temperatures of chlorite formation in the Strzelin and Borów granites is similar and varies from 326 to $371^{\circ} \mathrm{C}$. In the Strzelin granite the lowest temperatures are shown by chlorite grains in unaltered granite $\left(326^{\circ} \mathrm{C}\right)$ and the highest in the hydrothermal veins $\left(355^{\circ} \mathrm{C}\right)$. Chlorites formed within slightly and strongly altered granite show intermediate temperatures: 341 and $342^{\circ} \mathrm{C}$ respectively. In the Borów granite the highest temperature are given by chlorite grains crystallised in hydrothermal veins whereas temperatures of chlorites formed within the granite are lower and reach $343^{\circ} \mathrm{C}$ for unaltered granite and range from 317 to $361^{\circ} \mathrm{C}$ with a mean of $337^{\circ} \mathrm{C}$ for strongly but differently altered parts of granite. 
In both granites there is a slight difference in temperature calculated for analyses made within the rims and cores of chlorite grains (in the Strzelin granite $340^{\circ} \mathrm{C}$ and $341^{\circ} \mathrm{C}$ respectively and in the Borów granite $332^{\circ} \mathrm{C}$ and $336^{\circ} \mathrm{C}$ respectively). Furthermore, clear differences observed between spherulitic and post-biotite chlorites. The temperature of spherulitic chlorite crystallization is higher $\left(364^{\circ} \mathrm{C}\right.$ in the Strzelin granite and $344^{\circ} \mathrm{C}$ in the Borów granite) than that for the post-biotite chlorite $\left(340^{\circ} \mathrm{C}\right.$ and $342^{\circ} \mathrm{C}$ respectively).

On the basis of thermometric and barometric studies of fluid inclusions in quartz Stępisiewicz $(1977,1978)$ estimated the temperature of chlorite formation in hydrothermal veins in the Strzelin granite generally from two hundred and tens to a hundred and tens degrees Celsius. A detailed study of the crystallisation conditions of the post-magmatic minerals formed in pegmatites and hydrothermal veins was conducted by Kozłowski and Marcinowska (2007). The temperatures and pressures of chlorite formation in the Strzelin granite were inferred from fluid inclusions present in the growth zones of quartz or fluorite or calcite where chlorite grains were included. The chlorite crystallisation temperatures lie within three intervals: $300-260^{\circ} \mathrm{C}, 210-180^{\circ} \mathrm{C}$ and $160-150^{\circ} \mathrm{C}$. According to Janeczek (1985) the temperature of chlorite formation in the Strzegom-Sobótka Massif ranges from 400 to $230^{\circ} \mathrm{C}$.

\section{SUMMARY AND CONCLUSIONS}

Chlorite is one of the most common minerals formed in granitoids at the hydrothermal stage of their formation. The assemblage of hydrothermal minerals can differ in different massifs in the world, but usually it consists of titanite, laumontite, prehnite, calcite, muscovite, clay minerals, epidote, hematite and fluorite. These minerals, as well as chlorite, are found within the granite as alteration products or as crystals formed in fractures and microfractures. The presence of interstratified structures in investigated chlorites has generally been excluded.

Chlorite grains formed in unaltered Borów granite contain more iron than these formed in the Strzelin granite. The factor which can influence on chlorite composition is the $\mathrm{MgO} / \mathrm{FeO}$ ratio of the host rock, the $\mathrm{MgO} / \mathrm{FeO}$ ratio of the Strzelin granite being higher than that in the Borów granite. In hydrothermally altered parts of the granites investigated chlorite of spherulitic shape is slightly more ferruginous than post-biotite chlorite, depending mostly on the chemical composition of hydrothermal fluids and oxygen fugacity, which facilitates Fe-chlorite formation. The variability of chlorite composition in the five samples of strongly altered Borów granite can be explained by multiplefluxes of hydrothermal fluid of different concentrations of components or by oxygen fugacity variation as can happen in a large active shear zone.

Increasing temperatures of chlorite formation in gradually altered Strzelin granite and lower temperature of chlorite formed within the Borów granite than in the veins show that the temperature of the hydrothermal fluid penetrating granitic bodies was higher than the temperature of the Strzelin and Borów granites at that time. Increase of the $\mathrm{Al}^{\mathrm{IV}}$ contents towards the mineralisation zone may indicate increasing temperatures. Higher temperatures of spherulitic chlorite crystallisation directly from the fluid in veins indicates that this process takes less time than the process of biotite chloritisation, which starts with biotite breakdown by substitution of $\mathrm{K}^{+}$by $\mathrm{H}^{+}$followed by the alteration of tetraand octahedral sheets. This is supported by higher formation temperatures of spherulitic chlorite by comparison with post-biotite chlorite in the Strzelin and Borów granites.

The temperature of chlorite formation in the Strzelin granite proposed by Stępisiewicz (1977) was rather underestimated. Only the upper temperature range $210^{\circ} \mathrm{C}$ and higher is possible, as proposed by Kozłowski and Marcinowska (2007) for the first interval. The temperature of chlorite formation in the Borów granite is in line with the estimations proposed by Janeczek (1985) and can be limited to the range $300-400^{\circ} \mathrm{C}$. This means that chlorite in the Strzelin and Borów granites was formed mainly in the upper temperature range of the hydrothermal stage of granite formation. Therefore the temperature range of chlorite formation corresponds to the zeolitic-prehnite/pumpellyite facies of low-grade metamorphism. Calculated temperatures do not take into consideration the pressure, oxygen fugacity, activity of $\mathrm{Mg}^{2+}$ ions, sulphur concentration, $\mathrm{pH}$ or ionic concentration. Therefore, research still needs to be conducted to establish the dominant factor in the process of chlorite formation.

Acknowledgements. I would like to thank to G. Bzowska for XRD analyses and S. Duber for the HRTEM images. I am also very grateful to J. Janeczek, A. Lewandowska and E. Koszowska for many helpful comments and discussion. The present paper benefited greatly from two reviewers, including L. Krzemiński.

\section{REFERENCES}

BAILEY S. W. (1980) - Summary of recommendations of AIPEA nomenclature committee on clay minerals. Am. Miner., 65: 1-7.

BAILEY S. W. (1988) - Chlorites: structures and crystal chemistry. Rev. Miner., 19: 347-404.

BATTAGLIA S. (1999) - Applying X-ray geothermometer diffraction to a chlorite. Clays Clay Miner., 47 (1): 54-63.

BEREŚ B. (1969) - Petrography of the Strzelin granite and environs (in Polish with English summary). Arch. Miner., 7 (2): 6-115.

BORKOWSKA M. (1956) - The Strzelin granite and accompanied crystalline rocks (in Polish with English summary). Arch. Miner., 19 (1): $17-37$.
CATHELINEAU M. (1988) - Cation site occupancy in chlorites and illites as a function of temperature. Clay Miner., 23: 471-485.

CATHELINEAU M. and NIEVA D. (1985) - A chlorite solid solution geothermometer The Los Azufres (Mexico) geothermal system. Contr. Miner. Petrol., 91: 235-244.

CIESIELCZUK J. (2000a) - Geochemistry of the hydrothermally altered granite from the shear zone in Borów (Strzegom-Sobótka massif). Pr. Spec. PTM, 17: 132-134.

CIESIELCZUK J. (2000b) - Hydrothermal alteration of the granites from Strzelin and Borów (Sudetes Mts.) (in Polish). Unpubl. Ph.D. Thesis, University of Silesia, Poland. 
CIESIELCZUK J. (2002) - Chlorite from hydrothermally altered Strzelin and Borów granites (the Fore-Sudetic Block): an attempt of chlorite geothermometry application. Pr. Spec. PTM, 20: 74-76.

CIESIELCZUK J. (2007) - Hydrothermal activity in the Strzelin granite (Poland). Arch. Miner. Monograph., 1: 231-242.

CIESIELCZUK J. and JANECZEK J. (2004) - Hydrothermal alteration of the Strzelin granite, SW Poland. N. Jb. Miner. Abh., 179 (3): 239-264.

De CARITAT P., HUTCHEON I. and WALSHE J. L. (1993) - Chlorite geothermometry: a review. Clays Clay Miner., 41 (2): 219-239.

EGGLETON R. A. and BANFIELD J. F. (1985) - The alteration of granitic biotite to chlorite. Am. Miner., 70: 902-910.

FREY M. and ROBINSON D. (1999) - Low-grade metamorphism. Blackwell Science.

HAMASAKI S., TSUKIMURA K., FUJIMOTO K., OMURA K. and IKEDA R. (1995) - Alteration minerals in granitic rock at Ashio as radionuclide adsorption materials. Mat. Res. Soc. Symp. Proc., 353: $1275-1282$.

INOUE A., MEUNIER A., PATRIER-MAS P., RIGAULT C., BEAUFORT D. and VIEILLARD P. (2009) - Application of chemical geothermometry to low-temperature trioctahedral chlorites. Clays Clay Miner., 57: 371-382.

JANECZEK J. (1983) - Transformations of minerals in pegmatites from Strzegom (Lower Silesia) (in Polish with English summary). Arch. Miner., 39 (1): 39-51.

JANECZEK J. (1985) - Typomorphic minerals of pegmatites from the Strzegom-Sobotka granitic massif (in Polish with English summary). Geol. Sudet., 20 (2): 1-66.

JANECZEK J. (1994) - The effect of aluminous titanite on the biotite chlorite and amphibole-chlorite reactions. Eur. J. Miner., 6: 623-625.

JIANG W.-T., PEACOR D. R. and BUSECK P. R. (1994) - Chlorite geothermometry? Contamination and apparent octahedral vacancies. Clays Clay Miner., 42 (5): 593-605.

KOZLOWSKI A. and MARCINOWSKA A. (2007) - Hydrothermal activity in the Karkonosze, Strzegom and Strzelin massifs - a fluid inclusion study. Arch. Miner. Monograph., 1: 243-252.

KRANIDIOTIS P. and MacLEAN W. H. (1987) - Systematics of chlorite alteration at the Phelps Dodge massive sulfide deposit, Quebec. Econ. Geol., 82: 1898-1911.

KRZEMIŃSKI L. (2000) - Low-temperature metamorphism in external Variscides of western Poland: an application of chlorite geothermometers. Pr. Spec. PTM, 17: 204-207.

KURAL S. and MORAWSKI T. (1968) - The Strzegom-Sobótka granitic massif (in Polish). Biul. Inst. Geol., 227.

LÓPEZ-MUNGUIRA A., NIETO F. and MORATA D. (2002) - Chlorite composition and geothermometry: a comparative HRTEM/AEM-EMPA-XRD study of Cambrian basic lavas from the Ossa Morena Zone, SW Spain. Clay Miner., 37: 267-281.

MAJEROWICZ A. (1972) - On the petrology of the granite massif of Strzegom-Sobótka (in Polish with English summary). Geol. Sudet., 6: 7-96.

MERRIMAN R. J, ROBERTS B., PEACOR D. R. and HIRONS S. R. (1995) - Strain-related differences in the crystal growth of white mica and chlorite: a TEM and XRD study of the development of metapelitic microfabrics in the Southern Uplands thrust terrane, Scotland. J. Metamorph. Geol., 13 (5): 559-576.

OBERC-DZIEDZIC T. (1999) - 1. The metamorphic and structural development of gneisses and older schist series in the Strzelin Crystalline Massif (Fore-Sudetic block, SW Poland), 2. The geology of the Strzelin granitoids (Fore-Sudetic block, SW Poland). Pr. Spec. PTM, 14: $10-33$

OBERC-DZIEDZIC T. (2007) - Internal structure of the granite and tonalite intrusions in the Strzelin massif, Fore-Sudetic block, SW Poland. Arch. Miner. Monograph., 1: 217-229.

OBERC-DZIEDZIC T., PIN C., DUTHOU J. L. and COUTURIE J. P. (1996) - Age and origin of the Strzelin granitoids (Fore-Sudetic Block, Poland): ${ }^{87} \mathrm{Rb} /{ }^{86} \mathrm{Sr}$ data. N. Jb. Miner. Abh., 171 (2): 187-198.

OLIVES-BAÑOS J. O. and AMOURIC M. (1984) - Biotite chloritization by interlayer brucitization as seen by HRTEM. Am. Miner., 69: 869-871.
PARNEIX J. C. and PETIT J. C. (1991) - Hydrothermal alteration of an old geothermal system in the Auriat granite (Massif Central, France): petrological study and modelling. Chem. Geol., 89: 329-351.

PARRA T., VIDAL O. and THEYE T. (2005) - Experimental data on the Tschermak substitution in Fe-chlorite. Am. Miner., 90: 359-370.

PIN C., PUZIEWICZ J. and DUTHOU J.-L. (1989) - Ages and origins of a composite granitic massif in the Variscan belt: A Rb-Sr study of the Strzegom-Sobótka Massif, W. Sudetes (Poland). N. Jb. Miner. Abh., 160: $71-82$.

PLISSART G. and FÉMÉNIAS O. (2009) - Mineralogy and geothermometry of gabbro-derived listvenites in the Tisovita-Iuti ophiolite, southwestern Romania. Canadian Miner., 47: 81-105.

PUZIEWICZ J. (1990) - Strzegom-Sobótka granitic massif (SW Poland). Summary of recent studies. Arch. Miner., 45 (1-2): 135-154.

RYAN P. C. and HILLIER S. (2002) - Berthierine/chamosite, corrensite, and discrete chlorite from evolved verdine and evaporite-associated facies in the Jurassic Sundance Formation, Wyoming. Am. Miner., 87 (11-12): 1607-1615.

SCHMIDT D. and LIVI K. J. T. (1999) - HRTEM and SAED investigations of polytypism, stacking disorder, crystal growth, and vacancies in chlorites from subgreeenschist facies outcrops. Am. Miner., 84: $160-170$.

SHIKAZONO N. and KAWAHATA H. (1987) - Compositional differences in chlorite from hydrothermally altered rocks and hydrothermal ore deposits. Can. Miner., 25: 465-474.

STEPISIEWICZ M. (1977) - Physico-chemical conditions of post-magmatic mineral formation in Strzelin granitoids (in Polish with English summary). Arch. Miner., 33 (2): 61-71.

STĘPISIEWICZ M. (1978) - Hydrothermal laumontite from the Strzelin granitoids. Acta Geol. Pol., 28 (2): 223-233.

TURNIAK K., TICHOMIROWA M. and BOMBACH K. (2005) - Zircon $\mathrm{Pb}$-evaporation ages of granitoids from the Strzegom-Sobótka Massif (SW Poland). Pr. Spec. PTM, 25: 241-244.

VEBLEN D. R. and FERRY J. M. (1983) - A TEM study of the biotite-chlorite reaction and comparison with petrologic observations. Am. Miner., 68: 1160-1168.

VIDAL O., PARRA T. and TROTET F. (2001) - A thermodynamic model for $\mathrm{Fe}-\mathrm{Mg}$ aluminous chlorite using data from phase equilibrium experiments and natural pelitic assemblages in the $100^{\circ}$ to $600^{\circ} \mathrm{C}, 1$ to 25 kb range. Am. J. Sc., 301: 557-592.

VIDAL O., PARRA T. and VIEILLARD P. (2005) - Thermodynamic properties of the Tschermak solid solution in Fe-chlorite: application to natural examples and possible role of oxidation. Am. Miner., 90: 347-358.

WALSHE J. L. (1986) - A six-component chlorite solid solution model and the conditions of chlorite formation in hydrothermal and geothermal systems. Econ. Geol., 81: 681-703.

WILAMOWSKI A. (2002) - Chloritization and polytypism of biotite in the Łomnica granite, Karkonosze Massif, Sudetes, Poland: stable isotope evidence. Chem. Geol., 182 (2-4): 529-547.

XIE X., BYERLY G. R. and FERRELL R. E. jr (1997) - IIb trioctahedral chlorite from the Barberton greenstone belt: crystal structure and rock composition constraints with implications to geothermometry. Contr. Miner. Petrol., 126: 275-291.

XU H. and VEBLEN D. R. (1996) - Interstratification and other reaction microstructures in the chlorite-berthierine series. Contr. Miner. Petrol., 124: 291-301.

ZANG W. and FYFE W. S. (1995) - Chloritization of the hydrothermally altered bedrock at the Igarapé Bahia gold deposit, Carajás, Brazil. Miner. Depos., 30: 30-38.

ZANG Y., MUCHEZ Ph. and HEIN U. F. (1997) - Chlorite geothermometry and the temperature conditions at the Variscan thrust front in eastern Belgium. Geol. Mijnb., 76: 267-270.

ZIMÁK J. (1999) - Application of chlorite compositional geothermometres to hydrothermal veins in the variscan flysch sequences of the Nízký Jeseník Upland, to Alpine-type veins in the Sobotín region, and to the paragenesis with "strigovite" from Žulová massif and Strzegom-Sobótka massif. Acta Univ. Palackianae Olomucensis Facultas Rerum Naturalium, Geol., 36: 69-74. 